\title{
Price Gouging In A Hurricane: Do Free Market Forces Circumvent Price Controls?
}

\author{
Jesse T. Wright, Florida Gulf Coast University, USA \\ Raymond L. Placid, Florida Gulf Coast University, USA \\ Marcus T. Allen, Florida Gulf Coast University, USA
}

\begin{abstract}
This study analyzes gasoline prices in Florida and Georgia before and after Hurricane Irma, a major weather event that affected both states in 2017. The analysis reveals that gasoline prices in both states increased and stabilized well in advance of state of emergency declarations that triggered the states' price gouging laws. Price gouging laws thus appear to be inconsequential. Free market forces determine prices unhindered by government price controls during hurricane emergencies.
\end{abstract}

Keywords: Price Gouging; Free Market Forces; Government Price Controls; Gasoline Prices; Emergency; Hurricane

\section{INTRODUCTION}

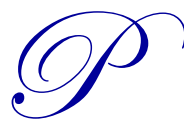

rice gouging laws are temporary government price controls often activated during states of emergency. Such laws are presumably intended to protect consumers from being charged unconscionable prices for basic necessities during emergency situations. While perhaps well-intentioned, price gouging laws seem to ignore the fundamental economic conclusion that price controls restrict free market forces from efficiently allocating scarce goods.

From an economic perspective, price gouging is nothing more than sellers responding to free market forces. In the event of a natural disaster or other widespread emergency, a demand increase for certain necessity goods may rapidly outstrip a supply increase, resulting in higher equilibrium prices. As Noel (2016) notes, consumers probably will not be happy about the price increase, but this is the way an efficient market clears. Eventually, the higher price of a good will entice more quantity supplied into the market and the price will adjust again accordingly. Price gouging laws may cap prices below the market clearing prices while quantity supplied is being increased, likely resulting in long waiting lines, hoarding behavior, and extended shortages.

Culpepper and Block (2008) claim that governments that enact price gouging laws are implicitly alleging that they know what consumers want better than entrepreneurial sellers who bear the risk of attempting to anticipate, assess, and respond to demand changes. Letting the invisible hand of a free market do its work is a more effective way to allocate scarce resources, especially in the case of essential commodities in emergency situations. Lee (2014), however, recognizes that the "mundane morality" of the invisible hand does not always satisfy public outrage related to the perceived price gouging. Consumers who feel emotional outrage at price gouging see the issue as a societal injustice, or moral failure, that they do not believe can be righted by free market forces and thus may appeal to political methods to address the perceived injustice (see Lee (2015)). In turn, politicians may implement anti-price gouging laws in search of their own political gain (see Noel (2016)).

The research question considered in this study is whether or not free market forces circumvented price gouging laws in Florida and Georgia that were triggered by a major weather event, Hurricane Irma, that dramatically impacted these states in September of 2017. This study first examines the legal roots of price gouging and considers these states' specific price gouging laws. Second, the study examines prices of gasoline, considered by law to be a basic necessity in both Florida and Georgia, before and after state of emergency declarations triggered the price gouging laws in these states. The results of the analysis described herein suggest that free market forces adjust gasoline prices well in advance of this type of emergency, thus circumventing the presumed intent of these states' price gouging laws. 


\section{PRICE GOUGING - LEGAL ROOTS}

In 1979, New York was the first state to enact a price gouging law ${ }^{1}$. Since then, 34 states have created their own price gouging rules either through legislation or administrative codes. There are no federal price gouging statutes.

State regimes for regulating price gouging are not identical, but they do share a common goal - to protect consumers from price gouging in times of widespread disaster. Most states' price gouging laws are rooted in the legal doctrine known as unconscionability. Unconscionable behavior is commonly construed to mean shockingly, unfair or unjust. ${ }^{2}$ In a legal sense, if a contract is unfair or oppressive to one party in a way that suggests abuses during its formation, a court may find it unconscionable and refuse to enforce it ${ }^{3}$.

The doctrine of unconscionability has two components - procedural and substantive. Procedural unconscionability is seen as the disadvantage suffered by a weaker party in negotiations to purchase goods or services ${ }^{4}$. In the context of price gouging, this occurs when a consumer, who is a victim of a disaster, purchases basic necessities from a profiteer at an inflated price. Substantive unconscionability is generally associated with the unfair or unreasonable terms that are contained in a contract ${ }^{5}$. Standing alone, the existence of procedural unconscionability is enough for a court to set aside a contract. Substantive unconscionability generally requires procedural unconscionability before the court will set aside a contract. These concepts permeate states' price gouging regimes that are presumably intended to protect consumers from paying unconscionable prices for basic necessities in times of a disaster. Governments that attempt to regulate price gouging put themselves in a legal quandary: price gouging activity may be easy to describe in statutes, but it is difficult to quantify in practice and, thus, price gouging laws are difficult to enforce.

\section{PRICE GOUGING LAWS - FLORIDA AND GEORGIA}

Florida and Georgia's price gouging laws are found in the consumer protection section of their statutes ${ }^{6}$. In general, consumer protection laws seek to preserve the competitive marketplace, to protect consumer choice, and to maintain the adequacy and the price of goods and services ${ }^{7}$. Florida and Georgia make price gouging illegal during a governordeclared state of emergency and use a look-back rule to determine if the laws have been violated. To illustrate, consider the following provisions from Florida and Georgia's price gouging statutes.

The Florida statutes state, in part, that:

It is unlawful ... for a person ... to sell ... at an unconscionable price ... any essential commodity. ... [T]he price of the commodity will be deemed unconscionable if the amount charged represents a gross disparity between the price of the commodity ... and the average price at which that commodity ... was sold ... 30 days immediately prior to a declaration of a state of emergency ${ }^{8}$.

\footnotetext{
${ }^{1}$ An Analysis Of The Enactment Of Anti-Price Gouging Laws, Cale Wren Davis (2008).

${ }^{2}$ A 50-State Report on Unfair and Deceptive Acts and Practices Statutes See Also Consumer Protection in the United States: Control of Unfair or Unconscionable Practices Phillip Blumberg University of Connecticut School of Law Carolyn L. Carter

${ }^{3}$ Williams v. Walker-Thomas Furniture Co., 350 F.2d 445 (D.C. Cir. 1965).

${ }^{4}$ Nichols v. YJ USA Corp., 2009 U.S. Dist. LEXIS 22450 (D. Tex. 2009).

${ }^{5}$ Lemke v. Arrowood, 2000 WI App 32 (Wis. Ct. App. 1999).

${ }^{6}$ See Fla. Stat. Chap. 501. (2018); See also, O.C.G.A. 10-1-393.4 (2010).

${ }^{7}$ Should the FTC's Current Criteria for Determining "Unfair Acts or Practices" Be Applied to State "Little FTC Acts"? David L. Belt

${ }^{8}$ Fla. Stat. $501 \S 160$
} 
The Georgia statutes state in part, that:

It shall be an unlawful ...for any person... to sell ... any goods necessary to preserve, protect, or sustain the life, health, or safety of persons ... at a price higher than the price at which such goods were sold or offered for sale immediately prior to the declaration of a state of emergency ${ }^{9}$.

In a legal sense, price gouging refers to unconscionable behavior that is shockingly unfair or unjust. Law enforcement authorities face a legal quandary when attempting to enforce price gouging laws because of the difficulty of showing that a price increase for a good in an emergency situation is so shockingly unfair or unjust that the price increase is illegal. Most states with price gouging laws employ some version of a look-back rule that compares the price of a good during a state of emergency (as declared by the governor of each state) to the price of the good prior to a state of emergency declaration. The basic premise of look-back rules is the same, but the key elements of the rules vary across states. These look-back rules may appear to be functional, but in practice they may not accomplish their presumed intended purpose in the case of an anticipated emergency such as a hurricane. To illustrate, consider the following example.

Smith operates a retail gasoline station in Georgia. During the month of August, Smith sells gasoline for $\$ 2.30$ per gallon and profits $\$ 0.05$ per gallon ${ }^{10}$. On September $1^{\text {st }}$, increasingly available information from weather forecasters and media outlets about an approaching hurricane and its projected track leads to an increase in demand from consumers evacuating the area by vehicle or storing gasoline as an emergency supply if they are intending to shelter in place. Smith increases the price of her gasoline to $\$ 2.70$ per gallon in response to the demand increase. On September $10^{\text {th }}$, the governor of Georgia declares a state of emergency because of the imminent threat of the approaching hurricane. (Presumably, declarations of states of emergency lead to increased operations that are costly to governments and thus are delayed or avoided in hurricane situations until forecasts are determined to have some (unspecified) degree of certainty.) The governor's declaration triggers the state's price gouging laws. During the state of emergency, Smith continues to sell gas at $\$ 2.70$ per gallon. Assuming Smith's cost does not increase (her cost per gallon is constant at $\$ 2.25$ ), her profit per gallon increases nine-fold to $\$ 0.45$.

In this example, Smith may be viewed as taking unfair advantage of consumers before and after the state of emergency declaration, but in fact she did not violate the state's price gouging laws. The Georgia statute provides, in part, that, under the state's look-back rule, it is unlawful to sell necessities, (e.g., gasoline) at a price higher than the price at which such goods were sold immediately prior to the declaration of a state of emergency. Smith increased the price of her gasoline to $\$ 2.70$ per gallon nine days prior to the declaration of a state of emergency. During the state of emergency, Smith continued to sell her gasoline for $\$ 2.70$ per gallon. Because the prices immediately before and after the state of emergency were the same, Smith did not violate Georgia's price gouging statute even though her profit was nine times higher after the state of emergency declaration.

If the example is modified such that Smith's gasoline station is in Florida, she would still not be in violation of that state's price gouging laws because she did not increase her price after the state of emergency was declared by that state's governor. But, even if she had increased price after the emergency declaration, it is still not clear that the price increase would be illegal because neither Florida's statutes nor case law quantifies the minimum magnitude of a "gross disparity." Is a $\$ 0.40$ price increase a gross disparity above the average price over the 30 -day period before the declaration of a state of emergency?

At least part of the reason Florida and Georgia's price gouging laws create a legal quandary in this example is due to the nature of the disaster in which the states are attempting to regulate price increases. Hurricanes strike with advance notice. The National Weather Service puts the public on notice well in advance of a hurricane making landfall. As a hurricane moves toward a region, media outlets tend to focus their coverage on the approaching storm and create substantial "hurricane hysteria." As hurricane hysteria escalates, demand for goods and the related prices begin to

\footnotetext{
${ }^{9} 2010$ Georgia Code Title 10 - COMMERCE AND TRADE Chapter 1 - SELLING AND OTHER TRADE PRACTICES E - 15. DECEPTIVE OR UNFAIR PRACTICES Part 2 - FAIR BUSINESS PRACTICES ACT § 10-1-393.4

${ }^{10} \mathrm{See}$ https://www.convenience.org/Topics/Fuels/The-Price-Per-Gallon - On average, it costs a retailer about 12 to 16 cents to sell a gallon of gasoline. Using the five-year average markup of 20.7 cents, the typical retailer averages about 5 cents per gallon in profit.
} 
increase well before the price gouging laws are triggered by a governor's declaration of a state of emergency. As a result, the price gouging statutes do not effectively interfere with free market forces.

Look-back rules may function better for governments seeking to regulate price gouging in unanticipated emergency situations such as an earthquake or tornado. These disasters strike without notice and market forces will not likely have time to adjust the price of goods before the disaster occurs. Georgia's price gouging law may be more easily enforced in such an emergency, but the ambiguity in Florida's price gouging law may make enforcement difficult even in unanticipated emergencies. The next sections of this study describe a specific hurricane event, Hurricane Irma, that impacted Florida and Georgia and analyze retail gasoline prices $(615,359$ observations from 13,061 retailers) over a 40-day period around the date of the hurricane.

\section{HURRICANE IRMA}

On August $30^{\text {th }}$, 2017, a tropical storm developed off the African coast. One day later, the storm reached hurricane status and was named Irma by the National Weather Service. By September $5^{\text {th }}$, Hurricane Irma reached sustained wind speeds of 185 miles per hour and became the strongest Category 5 hurricane ever recorded in the Atlantic basin. As Hurricane Irma set her eye on the Florida coast, media coverage from local and national news outlets and stateordered evacuations caused a mass exodus of citizens in the projected path of the storm ${ }^{11}$.

In anticipation of the storm's impact, Florida's Governor declared a state of emergency on September $4^{\text {th }}$. More than 6.5 million Floridians were ordered to evacuate their homes ${ }^{12}$. Georgia's Governor declared states of emergency for a number of Georgia counties starting on September $6^{\text {th }}$ and finally for the entire state on September $10^{\text {th }}$. The state of emergency declarations in Florida and Georgia triggered the states' price gouging laws previously described. On September $8^{\text {th }}$, two days before Hurricane Irma made landfall in Florida, Florida's Attorney General reported that the 24-hour price gouging hotline staffed by her office had received almost 7,000 consumer complaints in less than three days; a rate of more than 100 complaints per hour ${ }^{13}$.

On September $10^{\text {th }}$, Hurricane Irma made landfall in the lower keys of Florida and continued on a northerly path through Florida and Georgia as a major storm, gradually weakening before finally dissipating on September $13^{\text {th }}$ over southeast Missouri. The damages of Hurricane Irma, the fifth most costly storm to hit the U.S., are estimated at $\$ 50$ billion $^{14}$.

\section{GASOLINE PRICE ANALYSIS - HURRICANE IRMA}

The statistical analysis in this study first focuses on the general behavior of retail gasoline prices in Florida and Georgia in the days immediately before and after the declaration of a state of emergency on September $4^{\text {th }}$, 2017, in Florida. The focus then turns to differences in gasoline prices in the two states around the hurricane weather event for retail gasoline prices. Next, the analysis models the average retail gasoline prices for both Florida and Georgia using Fixed Effects (FE) regression analysis to test the hypothesis that retail gasoline prices increased significantly around the storm event. Finally, the analysis identifies individual stations where retail gasoline prices increased by at least 50 cents (a subjectively chosen amount) in the days following the states' declarations of state of emergency.

The data used in this analysis were obtained from OPIS and include daily retail prices and rack (wholesale) prices of regular-grade gasoline collected from 13,061 stations for Florida and Georgia over a 40-day period (a total of 615,359 observations from 13,061 retailers) ${ }^{15,16}$. The retail price data were collected by OPIS from credit-card swipes, the gasbuddy smart phone application, and self-reporting retailers.

\footnotetext{
${ }^{11}$ See Almasy et. al. 2017, CBS News 2017, and The New York Times 2017 for news reports preceding the hurricane.

${ }^{12}$ See NPR News 2017.

${ }^{13}$ CNBC interview on "Closing Bell," 4:03 pm ET, September 8, 2017. Note that the 7,000 consumer calls to the Florida price gouging hotline may include more than one call for a specific location, and that the price gouging reported may be on "essential" items other than gasoline-

${ }^{14}$ See https://www.thebalance.com/hurricane-irma-facts-timeline-damage-costs-4150395

${ }^{15}$ OPIS, By IHS Markit (www.opisnet.com).

${ }^{16}$ The database is an unbalanced panel. Approximately $98 \%$ of all stations appear in the database on a given day during the study period.
} 
Descriptive statistics for Florida and Georgia retail gasoline prices are shown in Tables 1 and 2. Tables 1 and 2 indicate the summary statistics for both Florida and Georgia in the 30-day period before the Florida state of emergency was declared, and in the 10-day period after the Florida state of emergency was declared, respectively.

Table 1. Summary Statistics - Gasoline Prices - 8/5/17 to 8/30/18

\begin{tabular}{l|c|c|c|c|c|c|c|}
\hline & Mean & Median & Sd & Min & Max & $\boldsymbol{N}$ \\
\hline Florida Retail Price (\$) & 2.49 & 2.51 & 0.22 & 1.57 & 4.60 & 350,736 \\
\hline Georgia Retail Price (\$) & 2.48 & 2.54 & 0.25 & 1.51 & 3.80 & 254,007 \\
\hline
\end{tabular}

Table 2. Summary Statistics - Gasoline Prices - 9/5/17 to 9/14/17

\begin{tabular}{l|c|c|c|c|c|c|}
\hline & Mean & Median & Sd & Min & Max & $\boldsymbol{N}$ \\
\hline Florida Retail Price (\$) & 2.68 & 2.70 & 0.10 & 1.98 & 4.60 & 180,099 \\
\hline Georgia Retail Price (\$) & 2.70 & 2.70 & 0.12 & 2.00 & 3.80 & 134,832 \\
\hline
\end{tabular}

Figure 1 shows average retail gasoline prices (measured in cents) from August $15^{\text {th }}$ to September $14^{\text {th }}$ for both Florida and Georgia. The data are presented in Figure 1 along a daily timeline centered on the Florida state of emergency declaration date of September $4^{\text {th }}$. The $\mathrm{x}$-axis represents the number of days before and after the Florida state of emergency declaration, and the vertical lines at $0,2,3$, and 6 days represent the Florida state of emergency declaration and the three subsequent Georgia state of emergency declarations, respectively.

Figure 1. Florida (FL) and Georgia (GA): Retail Average Prices. August $15^{\text {th }}-$ September $14^{\text {th }}$

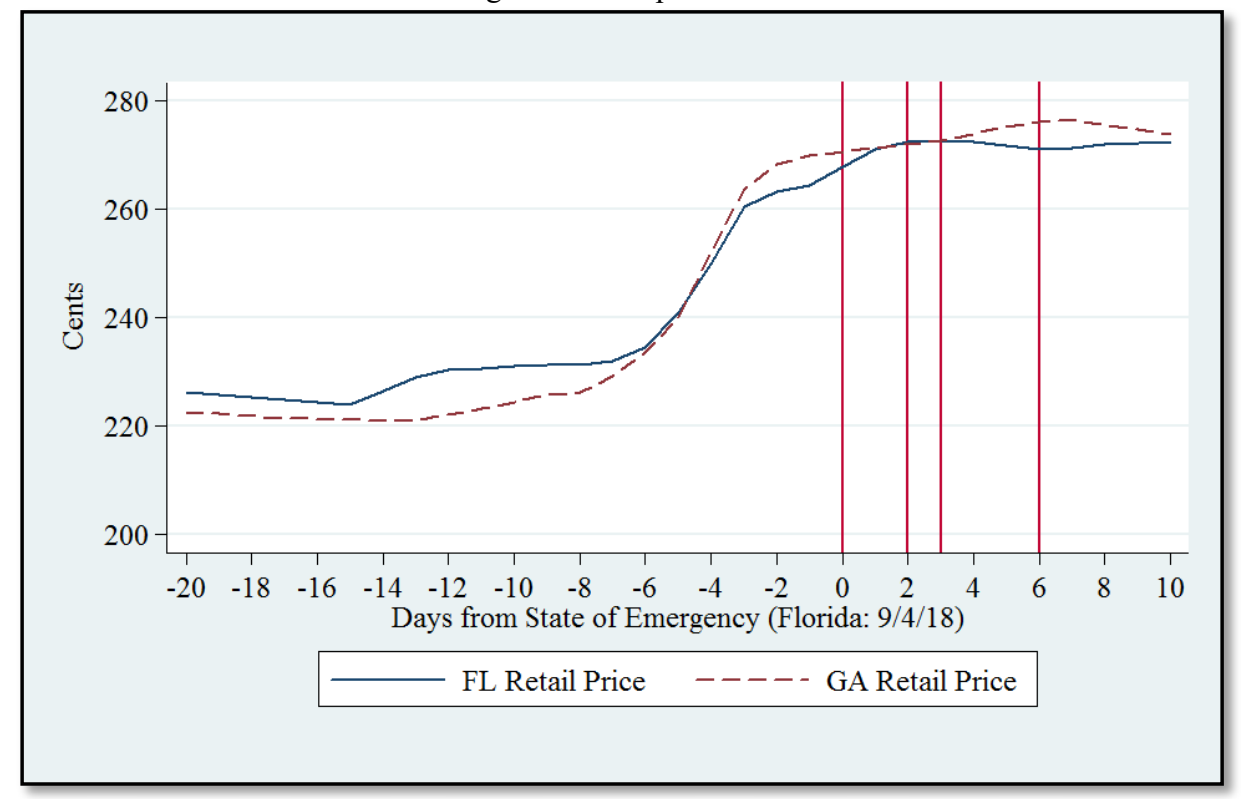

The first focus of the analysis centers on Figure 1. The chart indicates that Georgia gasoline prices changed in nearlockstep with Florida prices, suggesting that gasoline markets in both states reacted similarly around the Florida state of emergency declaration even though the state of emergency declarations in Georgia were made on September $6^{\text {th }}$, 
$7^{\text {th }}$, and $10^{\text {th } 17,18,19}$. Specifically, the data presented in Figure 1 shows that retail prices began reacting to Hurricane Irma approximately six days before the Florida state of emergency declaration in both Florida and Georgia. Prices approximately stabilized three days before the Florida state of emergency declaration and, by September $1^{\text {st }}$, average retail prices were close to their post-Irma levels. Based on these observations, the Florida state of emergency declaration date of September $4^{\text {th }}$ will be used in the following analysis to examine gasoline prices in both states.

The second focus of the analysis is on differences in gasoline prices in the two states around the hurricane weather event on retail gasoline prices in Florida and Georgia. Difference in means $t$-tests allow evaluation of gasoline prices to detect the possible impacts of Hurricane Irma statewide. Furthermore, difference in mean $t$-tests allow detection of possible storm effects on average gasoline prices at stations in both states located within one mile of an Interstate 75 (I-75) exit ramp or an Interstate 95 (I-95) exit ramp - the major evacuation routes for those leaving Florida and passing through Georgia ${ }^{20}$. Gasoline prices at stations within one mile of an exit ramp are compared to average prices from stations 5 miles or more from these exit ramps ${ }^{21}$.

\section{RESULTS}

Table 3 lists the $t$-test results for difference in means tests for Florida regular-grade retail gasoline prices. Model (1) of Table 3 tests the difference between the 10-day average price after September $4^{\text {th }}$, the date of state of emergency declaration in Florida, and the 30-day average price before September $4^{\text {th }}$. The positive and statistically significant difference for average retail price indicates that retail prices were approximately 39 cents higher in the ten days following September $4^{\text {th }}$.

Table 3. Difference in Means t-Test Results - Florida Gasoline Prices - State of Emergency: 9/4/17

\begin{tabular}{|c|c|c|c|c|c|}
\hline & $\begin{array}{c}\text { (1) } \\
\text { Prior 30-Day Avg. } \\
\text { vs. Post 10-Day Avg. }\end{array}$ & $\begin{array}{c}(2) \\
\text { 8/5 to 8/30: I75 vs. } \\
\text { Non-I75 }\end{array}$ & $\begin{array}{c}(3) \\
\text { 9/5 to 9/14: I75 vs. } \\
\text { Non-I75 }\end{array}$ & $\begin{array}{c}(4) \\
8 / 5 \text { to } 8 / 30: I^{\prime} 95 \text { vs. } \\
\text { Non-I95 }\end{array}$ & $\begin{array}{c}(5) \\
\text { 9/5 to } 9 / 14: \text { I95 vs. } \\
\text { Non-I95 }\end{array}$ \\
\hline \multirow[t]{2}{*}{ Retail Price (\$) } & $0.387^{* * *}$ & $0.011^{* * *}$ & $0.016^{* * *}$ & $0.043^{* * *}$ & $0.048^{* * *}$ \\
\hline & $(1040.04)$ & $(5.74)$ & $(15.71)$ & $(26.76)$ & $(41.90)$ \\
\hline$N$ & 357,028 & 235,655 & 121,384 & 246,239 & 126,679 \\
\hline
\end{tabular}

${ }^{\star}$ Location Comparisons: stations within a one-mile buffer vs. stations $5+$ miles from either I-75 or I-95.

$t$ statistics in parentheses

${ }^{*} p<0.05,{ }^{* *} p<0.01,{ }^{* * *} p<0.001$

Results from Models (2) and (3) of Table 3 indicate only negligible differences between prices at stations located within one mile of an I-75 exit ramp and prices at stations located further than 5 miles from I-75 before and after Hurricane Irma. Models (4) and (5) indicate that retail prices were higher by approximately four to five cents at stations near an I-95 exit ramp compared to retail prices at stations further than 5 miles from an I-95 exit ramp both before and after Hurricane Irma. Figure 2 presents the means used in Models (2) and (3) and Figure 3 presents the means used in Models (4) and (5) of Table 3.

Table 4 lists the $t$-test results of the regular-grade average retail gasoline prices in the state of Georgia. As the data presented in Figure 1 indicate, the results are notably similar to those from the Florida $t$-test analysis. Results of the 10-day average prices after the Florida state of emergency declaration minus the 30-day average before the Florida state of emergency declaration show an approximate increase of 36 cents.

\footnotetext{
${ }^{17}$ For three weeks in the following Georgia counties: Bryan, Camden, Chatham, Glynn, Liberty and McIntosh.

${ }^{18}$ For two weeks in the following Georgia counties: Appling, Atkinson, Bacon, Brantley, Bryan, Bulloch, Burke, Camden, Candler, Charlton, Chatham, Clinch, Coffee, Echols, Effingham, Emanuel, Evans, Glynn, Jenkins, Jeff Davis, Liberty, Long, McIntosh, Pierce, Screven, Tattnall, Toombs, Treutlen, Wayne and Ware.

${ }^{19}$ For one week in all Georgia counties.

${ }^{20}$ Straight-line distance.

${ }^{21}$ Straight-line distance measured with ArcGIS software using latitude and longitude coordinates.
} 
Figure 2. Florida (FL) Gasoline Price Means: I-75 vs. Non-I-75. August $15^{\text {th }}-25^{\text {th }}$ and September $5^{\text {th }}-14^{\text {th }}$

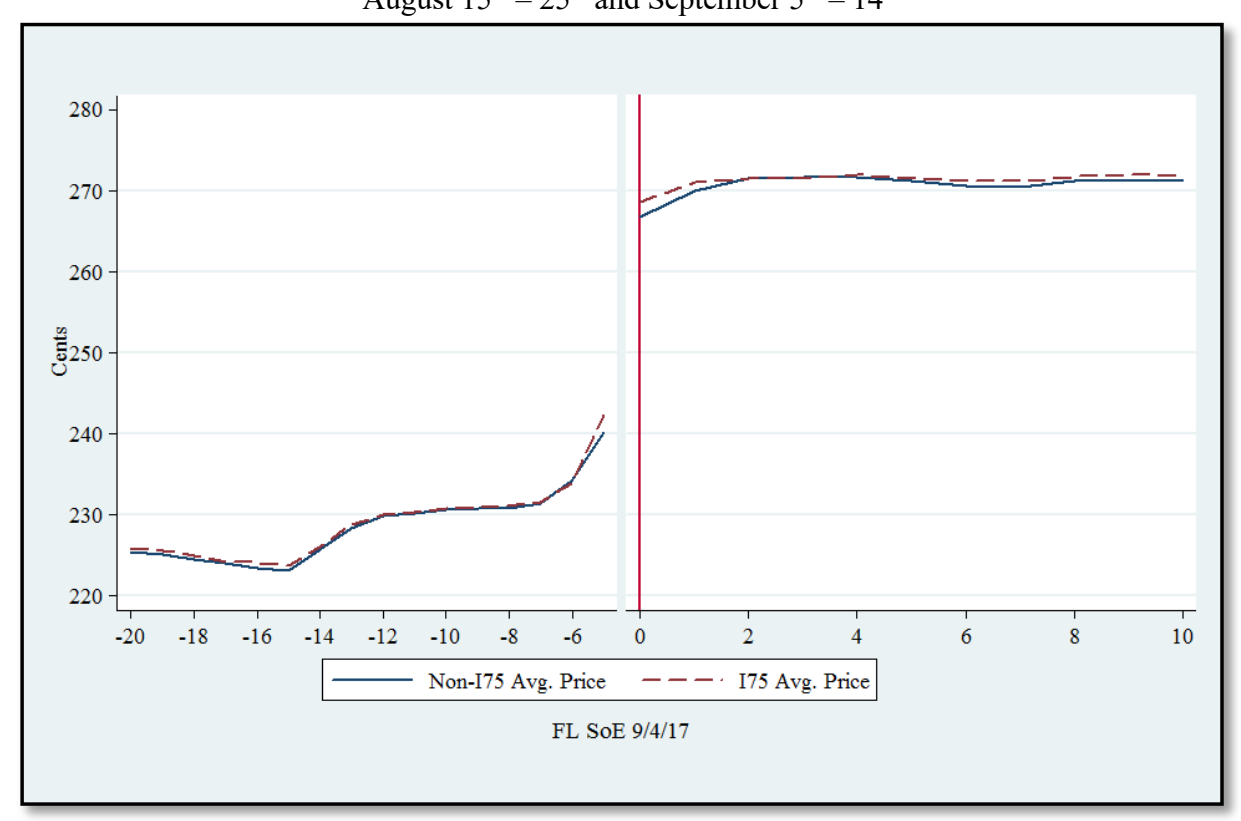

Figure 3. Florida (FL) Gasoline Price Means: I-95 vs. Non-I-95 August 15 th -25 th and September 5 th -14 th

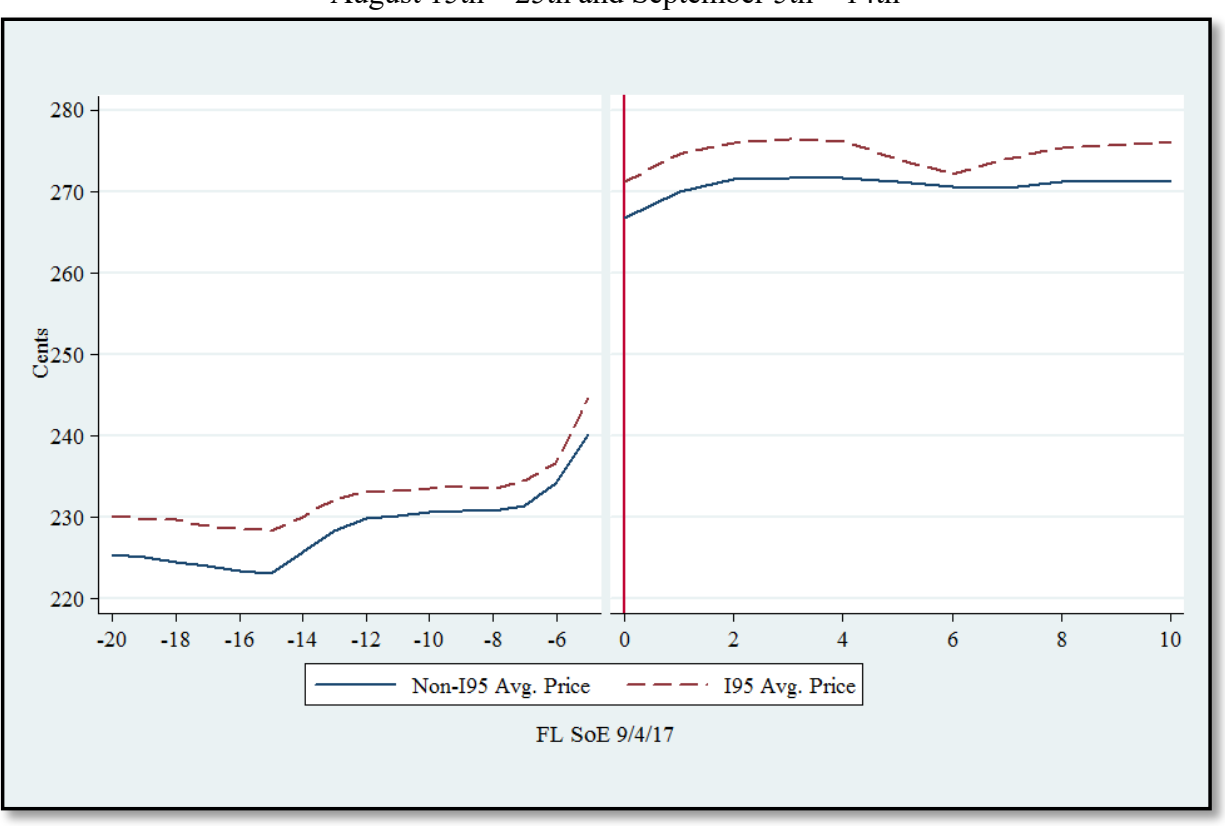

Models (2) and (3) in Table 4 presents Georgia $t$-test results for the differences in means of prices near to and far from I-75 exit ramps. Stations within one mile of an I-75 exit ramp in Georgia exhibit approximately two to three cents higher average retail prices than stations further than 5 miles from an I-75 exit ramp, but this spread does not appear to be affected by Hurricane Irma. The analysis for I-95 exit ramps, Models (4) and (5), indicates no increase in average retail gas prices related to the Irma timeline for stations within one mile of an I-95 exit ramp. The mean retail prices used in the Georgia interstate highway $t$-tests are presented in Figures 4 and 5 for I-75 and I-95, respectively. 
Table 4. Difference in Means $t$-Test - Georgia Gasoline Prices - State of Emergency: 9/4/17

\begin{tabular}{|c|c|c|c|c|c|}
\hline & $\begin{array}{c}(1) \\
\text { 8/27 - 9/5 Avg. vs. } \\
\text { 9/6 - 9/12 Avg. }\end{array}$ & $\begin{array}{c}(2) \\
\text { 8/5 to 8/30: I75 vs. } \\
\text { Non-I75` }\end{array}$ & $\begin{array}{c}(3) \\
\text { 9/5 to } 9 / 14: \text { I75 vs. } \\
\text { Non-I75 }\end{array}$ & $\begin{array}{c}(4) \\
\text { 8/5 to 8/30: I95 vs. } \\
\text { Non-I95 }\end{array}$ & $\begin{array}{c}(5) \\
\text { 9/5 to 9/14: I95 vs. } \\
\text { Non-I95 }\end{array}$ \\
\hline \multirow[t]{2}{*}{ Retail Price (\$) } & $0.363^{* * *}$ & $0.026^{* * *}$ & $0.029^{* * *}$ & $0.028^{* * *}$ & 0.005 \\
\hline & (396.04) & $(13.52)$ & $(21.72)$ & $(6.62)$ & $(1.68)$ \\
\hline$N$ & 166,657 & 208,072 & 110,535 & 189,840 & 100,779 \\
\hline
\end{tabular}

${ }^{\star}$ Location Comparisons: stations within a one mile buffer vs. stations 5+ miles from either I-75 or I-95. $t$ statistics in parentheses

${ }^{*} p<0.05,{ }^{* *} p<0.01,{ }^{* * *} p<0.001$

Figure 4. Georgia (GA) Gasoline Price Means: I-75 vs. Non-I-75 August 15 th -25 th and September 5 th -14 th

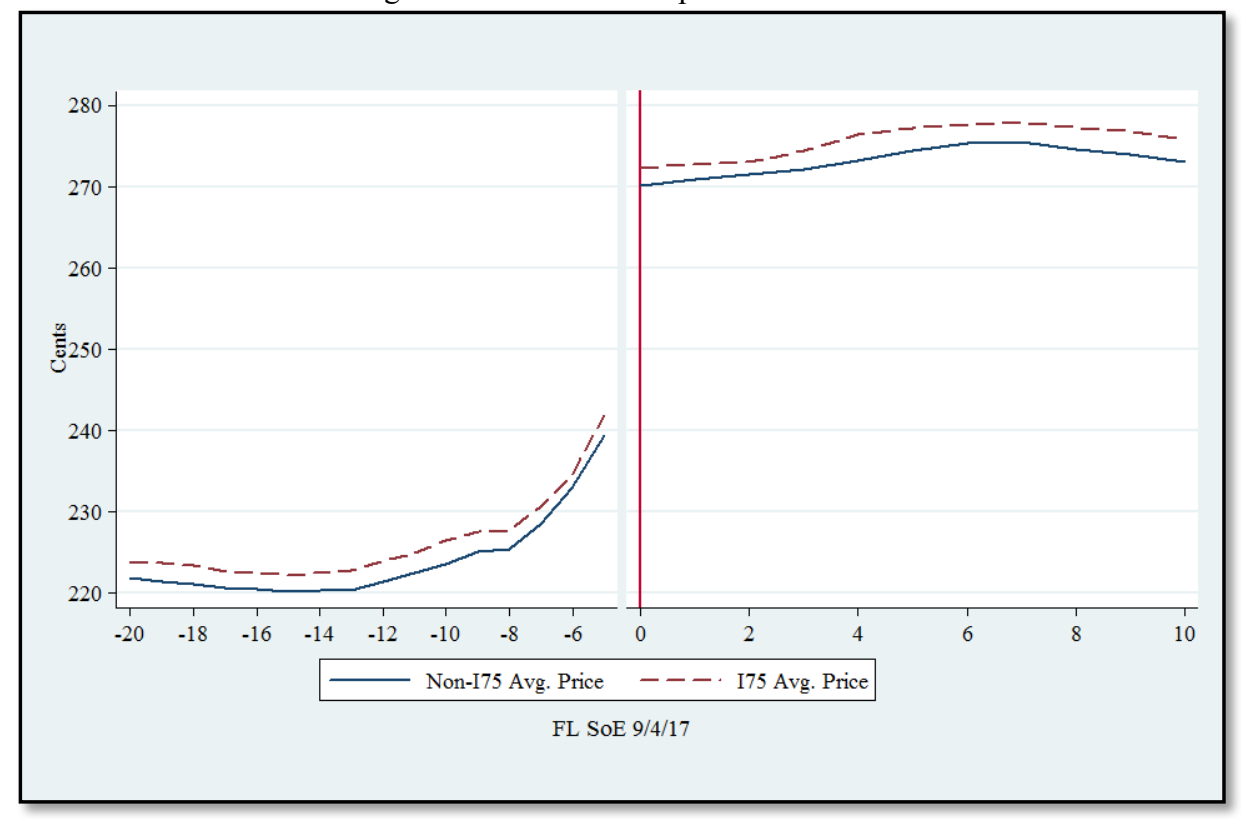


Figure 5. Georgia (GA) Gasoline Price Means: I-95 vs. Non-I-95 August 15 th -25 th and September 5th -14 th

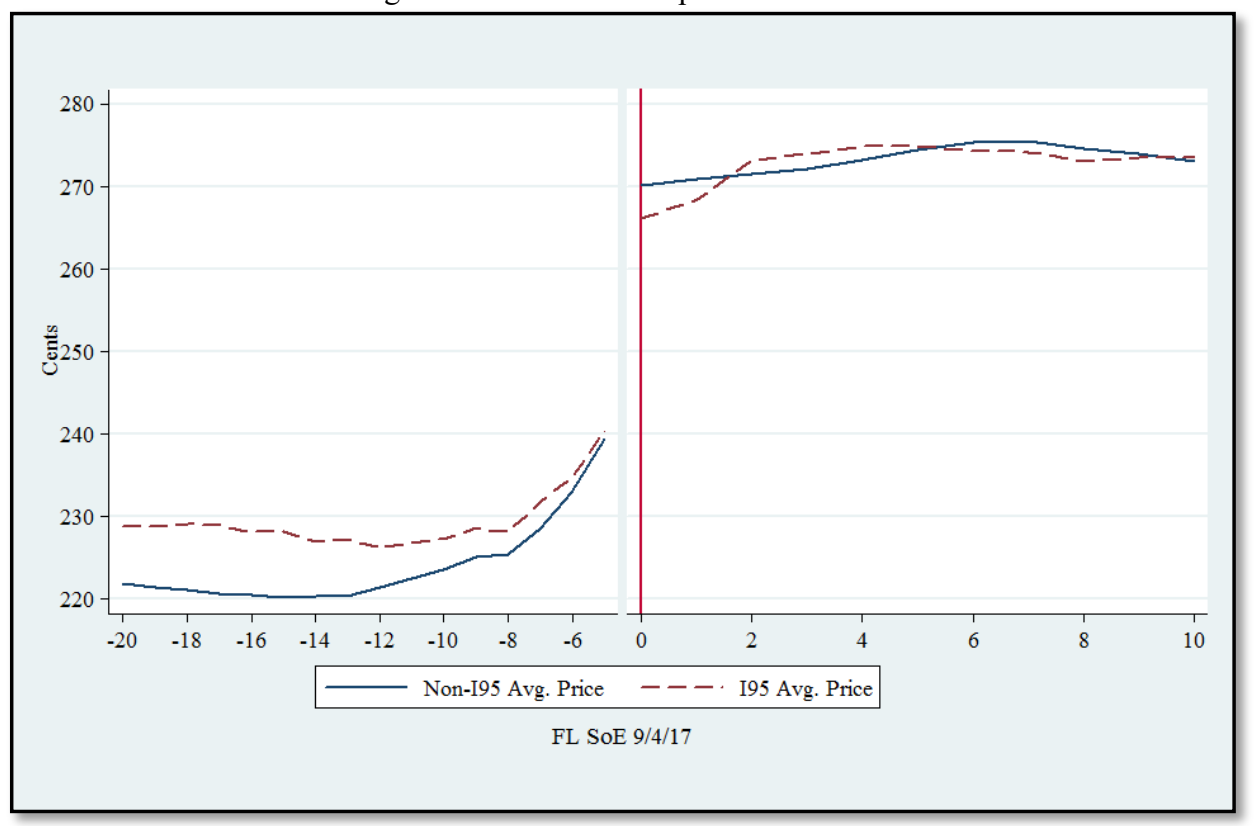

\section{PRICE MODELING}

The third focus of the analysis in this study is on modeling retail gasoline prices for both Florida and Georgia using Fixed Effects (FE) regression analysis. The FE models control for both station-specific (13,061 stations) and day of the week fixed effects, with the base model using average wholesale price as a primary determinate of average retail price. The alternate model includes an Irma dummy variable that takes a value of one if the date is after September $4^{\text {th }}, 2017$. These models are estimated in both linear and semi-log forms. The linear fixed effects model is presented in Equation (1).

Retail_Price $_{i t}=\propto+\beta_{1}$ Irma $_{\text {Binary }}{ }_{i t}+X \beta+\theta_{t}+\tau_{i}+\varepsilon_{i t}$

Where $\beta_{1}$ indicates the change in price when the $\operatorname{Irma}_{\text {Binary }}$ it changes from 0 to 1.

And $\beta$ is:

DRetail_Price

The fixed effects error term is $\tau, \theta$ is the time error term, and $\varepsilon$ is the regression error term. The coefficient of interest is $\beta_{1}$ : the change in retail price correlated with the Irma binary variable taking a value of 1 . The vector $X$ includes controls for day of the week and wholesale price.

Tables 5 and 6 present fixed effects (FE) regression results for Florida and Georgia, respectively, where the dependent variable is average retail price in Models (1) and (2) and the natural log of average retail price in Models (3) and (4). The coefficient on the Irma Dummy in Table 5, Model (2), indicates that the Hurricane Irma weather event correlates to a 26 cents premium in average retail price in Florida, which is smaller than the $t$-test result of 39 cents in Table 3. The $R^{2}$ in Model (2) with the Irma Dummy is approximately $27 \%$ higher than the $R^{2}$ in Model (1). The coefficient on 
the Irma Dummy variable in the semi-log form of the FE regression (Model (4)) indicates that the Hurricane Irma weather event relates to a $10.1 \%$ increase in average retail price ${ }^{22}$.

Table 6 presents the FE regression results for the state of Georgia. Comparing the $R^{2}$ s in Model (1) and Model (2) indicates that the FE model that includes the Irma dummy variable explains approximately $29 \%$ more of the variation in average retail gasoline prices. The coefficient on the Irma Dummy suggests that Hurricane Irma correlates to a 30 cents premium in average retail prices. The semi-log form of the model (Model (4)) indicates a $12.6 \%$ increase in average retail prices.

Table 5. Fixed Effects and Log Regression Results - Florida Gasoline Prices - Irma Effects on Retail Price

\begin{tabular}{|c|c|c|c|c|}
\hline Regression & $\begin{array}{c}\text { (1) } \\
\text { Base Price Model }\end{array}$ & $\begin{array}{c}\text { (2) } \\
\text { Irma Price Model }\end{array}$ & $\begin{array}{c}\text { (3) } \\
\text { Base Log Price Model }\end{array}$ & $\begin{array}{c}(4) \\
\text { Irma Log Price Model }\end{array}$ \\
\hline Irma Dummy & & $\begin{array}{l}25.897^{* * *} \\
(986.72)\end{array}$ & & $\begin{array}{l}0.101^{* * *} \\
(942.64)\end{array}$ \\
\hline Wholesale Price $(\phi)$ & $\begin{array}{l}1.066^{* * *} \\
(782.18)\end{array}$ & $\begin{array}{l}0.607^{* * *} \\
(720.90)\end{array}$ & & \\
\hline Wholesale Price (ln) & & & $\begin{array}{l}0.772^{* * *} \\
(837.05)\end{array}$ & $\begin{array}{l}0.447^{* * *} \\
(744.95)\end{array}$ \\
\hline Constant & $\begin{array}{l}65.968^{* * *} \\
(275.29)\end{array}$ & $\begin{array}{l}133.758^{* * *} \\
(948.20)\end{array}$ & $\begin{array}{l}1.543^{* * *} \\
(325.18)\end{array}$ & $\begin{array}{c}3.173^{* * *} \\
(1037.61)\end{array}$ \\
\hline$N$ & 357,028 & 357,028 & 357,028 & 357,028 \\
\hline $\mathrm{R}^{2}$ & 0.639 & 0.905 & 0.669 & 0.907 \\
\hline
\end{tabular}

${ }^{*}{ }^{t} p<0.05,{ }^{* *} p<0.01,{ }^{* * *} p<0.001$

Table 6. Fixed Effects and Log Regression Results - Georgia Gasoline Price - Irma Effects on Retail Price

\begin{tabular}{|c|c|c|c|c|}
\hline Regression & $\begin{array}{c}\text { (1) } \\
\text { Base Price Model }\end{array}$ & $\begin{array}{c}\text { (2) } \\
\text { Irma Price Model }\end{array}$ & $\begin{array}{c}\text { (3) } \\
\text { Base Log Price Model }\end{array}$ & $\begin{array}{c}\text { (4) } \\
\text { Irma Log Price Model }\end{array}$ \\
\hline Irma Dummy & & $\begin{array}{c}29.949^{* * *} \\
(818.78)\end{array}$ & & $\begin{array}{c}0.126^{* * *} \\
(804.98)\end{array}$ \\
\hline Wholesale Price $(\phi)$ & $\begin{array}{l}1.201^{* * *} \\
(608.94)\end{array}$ & $\begin{array}{l}0.690^{* * *} \\
(572.37)\end{array}$ & & \\
\hline Wholesale Price (ln) & & & $\begin{array}{c}0.872^{* * *} \\
(646.63)\end{array}$ & $\begin{array}{c}0.506^{* * *} \\
(596.87)\end{array}$ \\
\hline Constant & $\begin{array}{l}43.806^{* * *} \\
(126.92)\end{array}$ & $\begin{array}{l}117.522^{* * *} \\
(582.51)\end{array}$ & $\begin{array}{l}1.032^{* * *} \\
(148.90)\end{array}$ & $\begin{array}{l}2.862^{* * *} \\
(662.72)\end{array}$ \\
\hline$N$ & 258,331 & 258,331 & 258,331 & 258,331 \\
\hline $\mathrm{R}^{2}$ & 0.597 & 0.890 & 0.625 & 0.895 \\
\hline
\end{tabular}

$t$ statistics in parentheses

${ }^{*} p<0.05,{ }^{* *} p<0.01,{ }^{* * *} p<0.001$

\section{OBSERVATIONS OF APPARENT PRICE GOUGING}

Lastly, this study identifies the number of cases in which the 10-day average retail gasoline prices after the September $4^{\text {th }}$ increased in Florida by at least 50 cents above the 30-day average before September $4^{\text {th }}$ in Florida and the 7-day average before September $10^{\text {th }}$ in Georgia to reflect the language of the states' price gouging statutes. The amount of disparity considered here - 50 cents or greater - is subjectively chosen because, as discussed earlier, neither states' laws explicitly define dollar or percentage amounts that violate relevant statutes.

The data indicate that Florida has 70 unique stations in which the average retail price was at least 50 cents more than the pre-Irma price on at least one day during the time window specified above. The maximum increase for average

${ }^{22}$ Reflecting Kennedy's $(1981,1986)$ adjustment to coefficients on a dummy variable from semi-log form regressions. 
retail price observed at a station in Florida is 122 cents. The number of unique stations in Georgia with price increases greater than 50 cents was 19. The maximum increase in average retail price observed in Georgia is 78 cents.

\section{CONCLUSIONS}

The analysis of the price adjustments in the Florida and Georgia gasoline markets before and after Hurricane Irma presented in this study suggest that free market adjustments before the state of emergency declarations negate the states' attempts to regulate price increases. Before price gouging laws are triggered, the prices of necessity goods (e.g., gasoline) are determined by free market principles and prices adjust in accordance with those principles. To the extent that prices of necessity goods increase and stabilize before the state of emergency declaration, market forces circumvent price gouging laws.

Furthermore, each state's versions of the look-back rule for identifying price gouging behavior appears to be ineffective in the case of hurricanes. Unlike tornados and earthquakes - which strike with little or no warning, the general public is well aware in advance of an approaching hurricane. If the price charged for gasoline (or other necessity goods) in Florida or Georgia during a state of emergency is the same as the priced charged prior to a state of emergency declaration, price gouging statutes in these states are not violated under the look-back rule. Additionally, if there is sufficient ambiguity in the minimum magnitude of a price increase required to be classified as a "gross disparity" in Florida, prosecuting any suspected price gouger is unlikely to be successful.

In general, the analysis presented in this study suggests that free market forces adjust gasoline prices well in advance of state of emergency declarations for anticipated emergencies, thus circumventing the presumed intention of price gouging laws in such situations. As noted by an anonymous reviewer, future research that considers other critical consumer goods markets during emergency situations may be fruitful. Do the markets for gasoline and bottled water or fresh foods behave similarly around declarations of states of emergency? Also, additional analysis using data from other governmental jurisdictions and from other cultural areas around the world could provide useful insights about the impact of price gouging laws. Price gouging laws themselves vary across jurisdictions and local and global cultural norms may be reflected in the adoption and enforcement of such laws. The inferences offered in the present study are tempered, of course, by the fact that the data analyzed are from only two U.S. states. Analysis of other data sets (for different goods or from different jurisdictions and cultures) may bolster or contradict the findings presented here.

\section{AUTHOR BIOGRAPHIES}

Jesse T. Wright. Jesse Wright graduated from Florida State University with a Ph.D. in Economics and now teaches economics at Florida Gulf Coast University.

Raymond L. Placid. Raymond Placid is a Professor of Accounting at Florida Gulf Coast University.

Marcus T. Allen. Tim Allen holds the Alico Chair in Finance at Florida Gulf Coast University.

\section{REFERENCES}

Almasy, S., Hanna, J., \& Karimi, F. (2017, September 9). Hurricane Irma responsible for 10 deaths, threatens Miami. Retrieved from https://www.cnn.com/2017/09/07/us/hurricane-irma-caribbean-florida/index.html

Block, W., Culpepper, D. and Block, W. (2008), "Price gouging in the Katrina aftermath: free markets at work", International Journal of Social Economics, Vol. 35 No. 7, pp. 512-520. https://doi.org/10.1108/03068290810886911

CBS News (2017, September 10). Hurricane Irma makes landfall in lower Florida Keys. Retrieved from https://www.cbsnews.com/news/hurricane-irma-track-update-florida-path-live-09-09-2017/

Kennedy, P.E. (1981). Estimation with correctly interpreted dummy variables in semilogarithmic equations. American Economic Review, 71(4) 801.

Kennedy, P.E. (1986), Interpreting dummy variables. The Review of Economics and Statistics, 68(1) 174-175.

Lee, D.R. (2014). The two moralities of outlawing price gouging. Regulation, Spring 28-31.

Lee, D.R. (2015). Making the case against 'price gouging' laws. The Independent Review, 19(4) 583-598.

Noel, M.D. (2016). Pricing strategies and litigation risks: an economic analysis of the downstream petroleum industry. Journal of Competition Law \& Economics, 12(2) 287-311. 
NPR News (2017, September 9). As Irma shifts west, powerful winds batter Florida Keys. Retrieved from https://www.npr.org/sections/thetwo-way/2017/09/09/549704585/-the-storm-is-here-floridians-window-to-evacuateshrinks-as-irma-bears-down.

The New York Times (2017, September 9). Storm gains strength as it nears Florida. Retrieved from https://www.nytimes.com/2017/09/09/us/hurricane-irma-florida.html. 